\title{
Mast cells, cytokines and asthma
}

\author{
ANTHONY E REDINGTON MRCP(UK), PETER H HOWARTH BSc(Hons) DM FRCP \\ Faculty of Medicine, University of Southampton, Southampton General Hospital, \\ Southampton UK
}

\begin{abstract}
AE Redington, PH Howarth. Mast cells, cytokines and asthma. Can J Respir Dis 1994;1(2):118-127.
\end{abstract}

The appreciation that asthma is a chronic inflammatory disorder of the airways has led to a reappraisal of the importance of different cell populations within the bronchial mucosa with respect to their role in the regulation of the cellular events in this disease. While mast cell degranulation has been implicated in the acute allergic bronchoconstrictor response, activation of this cell population has not been considered relevant to either the late phase inflammatory cell influx within the airways following allergen bronchoprovocation or to the mucosal eosinophilia in chronic clinical disease. As such, attention has focused on the T lymphocyte as an orchestrator of these cellular events on account of its ability to synthesize and release cytokines relevant to the allergic process. It is now, however, realized that many cell populations within the airways are able to generate cytokines comparable with and complimentary to those produced by $\mathrm{T}$ lymphocytes and that asthma cannot be considered an inflammatory airway disorder dependent upon activation of one single cell population. This review details the current evidence that airway mast cells synthesize, store and release cytokines relevant to allergic inflammation and considers their potential involvement not only in the cellular influx within the airways but also in the fibrotic structural changes which are evident in chronic disease.

Key Words: Asthma, Inflammation, Interleukin-4, Interleukin-5, Interleukin-6, Mast cells, Tumour necrosis factor-alpha

\section{Les mastocytes, les cytokines et l'asthme}

RÉSUMÉ : L'appréciation de l'asthme comme trouble inflammatoire chronique des voies aériennes a entraîné une réévaluation de l'importance des diverses populations de cellules dans la muqueuse bronchique quant à leur rôle régulateur des événements cellulaires se produisant dans cette maladie. $\mathrm{Si}$ la dégranulation des mastocytes a été impliquée dans la réaction bronchospastique allergique immédiate, le rôle de l'activation de cette population de cellules dans l'afflux cellulaire inflammatoire de la réaction retardée dans les voies aériennes suite à un test de provocation bronchique avec un allergène, et dans l'éosinophilie de la muqueuse identifiée dans la maladie chronique, n'a pas été retenu. À ce titre, l'attention s'est portée vers le lymphocyte T comme cellule orchestre de ces événements, à cause de sa capacité à synthétiser et à libérer des cytokines intervenant dans le processus allergique. Cependant, on sait maintenant que de nombreuses populations de cellules dans les voies aériennes peuvent générer des cytokines comparables et complémentaires à celles produites par les lymphocytes T. Il s'ensuit que l'asthme ne peut être considéré comme un trouble inflammatoire des voies aériennes tributaire de l'activation d'une seule population de cellules. Cette revue présente en détail les données actuelles démontrant que les mastocytes des voies aériennes synthétisent, emmagasinent et libèrent des cytokines jouant un rôle dans l'inflammation allergique et considère qu'ils participent probablement à l'afflux cellulaire dans les voies aériennes, mais aussi à la constitution de lésions de fibrose observées dans la maladie chronique.

Correspondence and reprints: Dr Anthony E Redington, University Medicine, Level D, Centre Block, Southampton General Hospital, Tremona Road, Southampton SO9 4XY, United Kingdom. Telephone (011-44) 703796 889, Fax (011-44) 703701771 
$\mathrm{H}_{\mathrm{c}}^{\mathrm{sis}}$ ISTORICALLY, THE MAST CELL HAS HAD A LONG ASSOciation with asthma, dating from the early identification of histamine as a mediator of anaphylactic reactions (1) and its subsequent localization to the mast cell (2). Mast cells are found throughout the respiratory tract where they are presumed to play a physiological role in host defence. They are large cells, 5 to $15 \mu \mathrm{m}$ in diameter, and contain within their cytoplasm numerous secretory granules which have characteristic scroll, lattice and grating appearances when viewed by transmission electron microscopy. These granules contain histamine and neutral proteases such as tryptase and chymase, all of which are stored in a preformed state and which are rapidly released in response to cross-linkage of cell surface-bound immunoglobulin (Ig) E by allergen. In addition, mast cell activation leads to the release of newly generated lipid mediators, including prostaglandin (PG) $\mathrm{D}_{2}$ and the sulphidopeptide leukotrienes, leukotriene (LT)C4 and its metabolites $\mathrm{LTD}_{4}$ and $\mathrm{LTE}_{4}$. In comparison with histamine, $\mathrm{LTC}_{4}, \mathrm{LTD}_{4}$ and $\mathrm{LTE}_{4}$ are extremely potent spasmogenic mediators, and they constitute the activity previously known as 'slow reacting substance of anaphylaxis' (3). There is good evidence that these spasmogenic mediators along with $\mathrm{PGD}_{2}$ are responsible for the early bronchoconstrictor response seen in sensitized asthmatics following allergen challenge. These mediators are recovered in increased quantities following local endobronchial allergen challenge in asthma (4-6), and histamine (7), $\mathrm{PGD}_{2}(8)$ and leukotriene receptor antagonists (9) all attenuate the airway response to allergen.

During the past decade the concept of asthma as a chronic inflammatory disorder has become widely accepted. Early evidence in support of this came from a number of studies examining either post-mortem tissue from patients who had died of acute severe asthma (10-13) or biopsies obtained from living asthmatics using rigid bronchoscopy $(14,15)$. More recently the availability of fibreoptic bronchoscopy as a means to obtain specimens and the development of more rigorous methods of quantification have enabled a detailed characterization of the pathological findings not only in allergic asthma (16-21) but also in other forms such as intrinsic (22) and occupational $(23,24)$ asthma. Taken together these studies have revealed that, irrespective of the presumed etiology, a key pathological feature of asthma is the presence of a chronic inflammatory infiltrate within the airway.

This change in emphasis from viewing asthma as an abnormality of bronchial smooth muscle tone to a disorder characterized by chronic inflammation has been accompanied by a decline in the importance attached to the immediate airway response to allergen challenge and by inference to the mast cell. As short acting beta-agonists, which in vitro inhibit IgE-dependent activation of human lung mast cells (25), have no influence on the late airway response following allergen challenge (26), it has been considered that the mast cell does not play a significant part in events leading to the development of airway inflammation and bronchial hyperreactivity. Similarly, as short acting beta-agonists do not improve the long-term pattern of asthma severity (27), and as novel 'antiallergic' compounds, which inhibit mast cell degranulation in

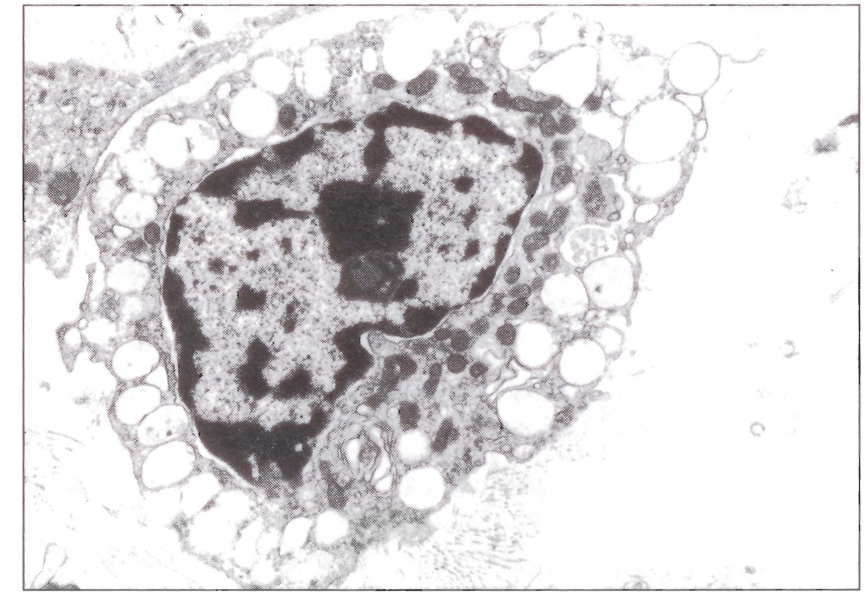

Figure 1) Transmission electron micrograph (x3360) of a subepithelial mast cell in a biopsy from a subject with stable asthma. There is extensive loss of granule contents. (Courtesy of Mrs S Wilson)

animal models, have failed to demonstrate clinical efficacy in human asthma (28), it has also been considered that mast cell activation does not contribute significantly to the pathogenesis of airway inflammation in clinical asthma. Thus, recent emphasis has been directed towards the T lymphocyte, with its ability to synthesize cytokines, as the key cell in coordinating the cellular events that occur following allergen challenge and in clinical disease.

However, while T lymphocyte activation and the potential for cytokine production by these cells are increased in asthma, it is now appreciated that the selective focus on one particular cell is misplaced as many cell types have the potential to contribute to the 'cytokine pool' within the airways. Mast cell activation is known to occur in clinical asthma, with ultrastructural features on transmission electron microscopy of partial degranulation $(16,29)$ (Figure 1), evidence of increased histamine release by bronchoalveolar lavage (BAL) fluid mast cells from asthmatics ex vivo $(30,31)$ and the identification of increased recovery of mast cell mediators in BAL fluid $(5,32,33)$. The recognition that, in addition to these 'classical' mediators, mast cell activation can also lead to the release of cytokines has renewed interest in the potential involvement of this cell type in the orchestration of airway inflammation.

\section{CYTOKINE PRODUCTION BY MAST CELLS}

The initial investigations of cytokine generation by mast cells were performed using long term murine mast cell lines. Abelson murine leukemia virus (AbMuLV)-transformed mast cell lines were shown to produce the cytokines, granulocyte-macrophage colony-stimulating factor (GM-CSF) (34,35), interleukin (IL)-3 (35) and IL-4 (36). Subsequently it was reported that nontransformed IL-3-dependent mast cell lines were able to generate IL-3, IL-4, IL-5 and IL-6 when stimulated by cross-linkage of FceR1 (37). These observations were confirmed, and the range of cytokines produced by activated murine mast cell lines was extended to include IL-1, IL-2, GM-CSF, interferon (IFN) $\gamma$ and four members of 
TABLE 1

Cytokines known to be produced by human mast cells and their actions in relation to allergic inflammation

\begin{tabular}{ll}
\hline Cytokine & Actions relevant to asthma \\
\hline TNF- $\alpha$ & Increases eosinophil cytotoxicity \\
& Monocyte chemoattractant \\
Increases endothelial expression of ICAM-1. \\
E-selectin and VCAM-1 \\
Induction of bronchial hyperreactivity \\
Interleukin-4 & Activates B lymphocyte by increasing \\
& expression of CD23 and class II major \\
histocompatibility complex & Induces isotype switching of B lymphocytes for \\
immunoglobulin E synthesis \\
Increases endothelial expression of VCAM-1 \\
Eosinophil chemoattractant
\end{tabular}

Interleukin-5 Enhances eosinophil differentiation

Prolongs eosinophil survival

Eosinophil chemoattractant

Primes eosinophils for increased functional activity

Interleukin-6 Activation of T lymphocytes

Terminal differentiation of B lymphocytes

Interleukin-8 Chemoattractant for:

-neutrophils

-eosinophils (when primed by exposure to other cytokines)

-T lymphocytes

ICAM-1 Intercellular adhesion molecule-1; TNF- $\alpha$ Tumour necrosis factor- $\alpha$; VCAM-1 Vascular cell adhesion molecule-1

the chemokine family, monocyte chemoattractant protein$1 / \mathrm{JE}$, macrophage inflammatory protein- $1 \alpha$, macrophage inflammatory protein- $1 \beta$ and $T$ cell activation antigen-3 (38).

Production of several of these cytokines was next demonstrated in primary cultures of murine bone marrow-derived mast cells and/or purified peritoneal mast cells in response to IgE-dependent activation, in particular IL-3 and GM-CSF (39), IL-1 and IL-6 (38) and tumour necrosis factor (TNF)- $\alpha$ (40). In these studies mRNA synthesis generally preceded cytokine release, which was not maximal until several hours after stimulation, and accordingly it was concluded that the cytokines were newly synthesized. In one study, however, it was shown that mast cell activation resulted not only in the rapid release of preformed TNF- $\alpha$ stored in granules, but also in an increase in TNF- $\alpha$ mRNA accompanied by further sustained release of newly synthesized TNF- $\alpha$ (41).

These findings have now in part been extended to human mast cells. Table 1 lists those cytokines currently recognized, together with some of their major actions which are believed relevant to allergic inflammation. TNF- $\alpha$ was the first cytokine to be clearly associated with human mast cells. This cytokine is able to increase the expression of endothelial adhesion molecules, which are believed to be important in the recruitment of inflammatory cells into the airways from the peripheral circulation, in particular E-selectin (42), intercellular adhesion molecule-1 (ICAM-1) $(42,43)$ and, when acting in synergy with IL-4, vascular cell adhesion molecule-
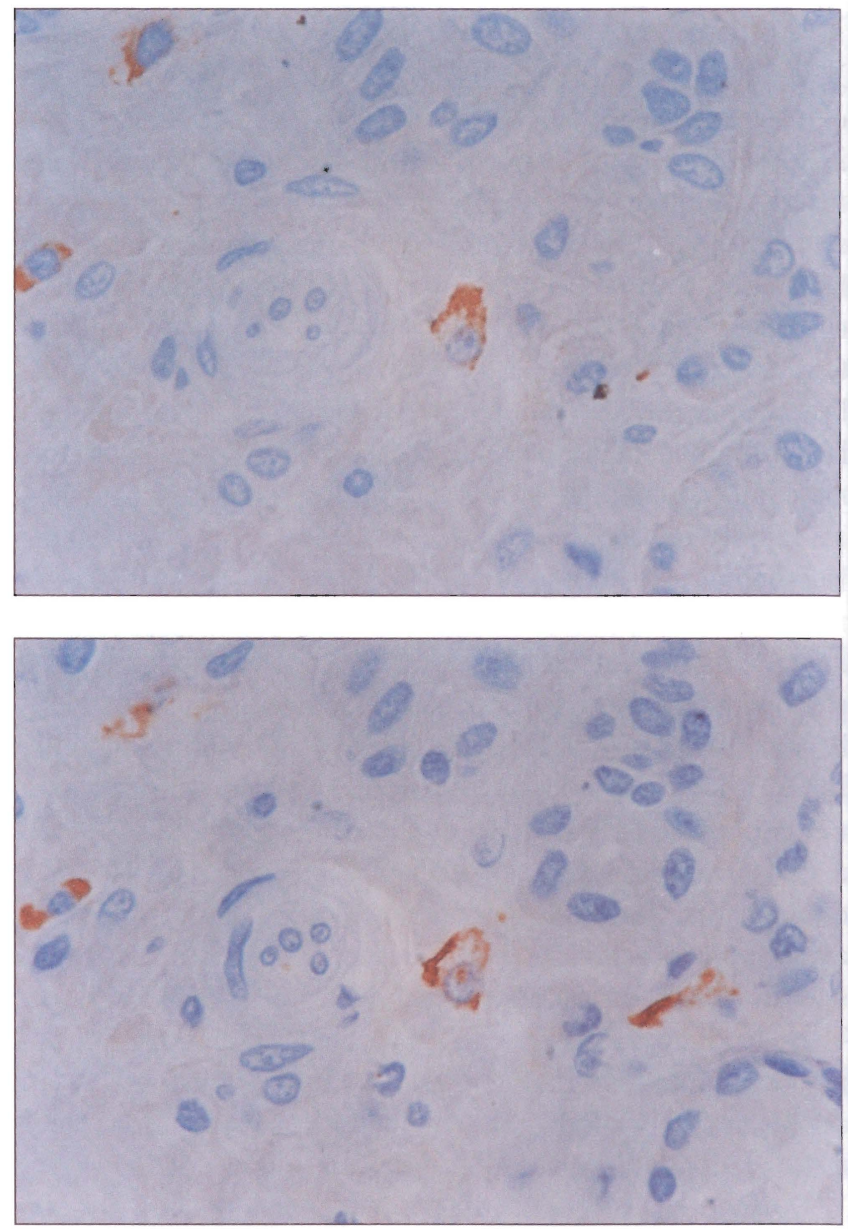

Figure 2) Use of sequential $2 \mu \mathrm{m}$ sections to determine the cellular provenance of cytokines. Top Stain using the monoclonal antibody AAl directed against mast cell tryptase; Bottom Stain using an antibody to the cytokine tumour necrosis factor (TNF)- $\alpha$. There is colocalization of immunoreactivity for both mediators to the same cells in these adjacent sections indicating that mast cells within the airway wall are a source of TNF- $\alpha$. (Courtesy of Dr P Bradding)

1 (VCAM-1) (44). In addition, it exerts a priming effect on eosinophils with respect to cytotoxic ability $(45,46)$ and superoxide generation (46); it is chemotactic for monocytes (47); and it induces bronchial hyperreactivity in experimental animals $(48,49)$. Purified human skin mast cells were first demonstrated to synthesize and release TNF- $\alpha$ in response to IgE-dependent activation (50). This cytokine is stored preformed in mast cell granules (51) and, using a skin culture system, the rapid release of TNF- $\alpha$ from these stores in response to anti-IgE or other stimuli was shown to lead to increased expression of E-selectin on the endothelium of adjacent postcapillary venules $(51,52)$. Immunoreactive TNF- $\alpha$ has also been localized to human lung mast cells, using the techniques of both dual staining (53) and examination of adjacent sections (54) (Figure 2); the proportion of mast cells expressing this cytokine is increased in asthma suggesting a role in disease expression (54). It remains to be determined whether human mast cells can synthesize both soluble and membrane-associated forms of TNF- $\alpha$, as has recently been reported for rodent mast cells (55). 
A second cytokine produced by human mast cells is IL-4. Purified human lung mast cells contain preformed IL-4, which is released in response to IgE-dependent activation (56). Furthermore, immunoreactivity for this cytokine has been localized to mast cells in bronchial mucosal biopsies (56) and, as with TNF- $\alpha$, there is some evidence that the proportion of mast cells expressing IL-4 is increased in asthmatics (54). IL-4 is likely to be important in the recruitment of inflammatory cells in allergic inflammation. It regulates leukocyte-endothelial adhesion by increasing the endothelial expression of VCAM-1, a molecule that may be of particular relevance to the recruitment of eosinophils through its interaction with the $\beta 1$ integrin VLA-4 which is expressed on eosinophils but not neutrophils (44,57,58); IL-4 also acts as an eosinophil chemoattractant (59). In addition IL-4 activates B lymphocytes and is recognized to be a critical factor in isotype switching for $\operatorname{IgE}$ synthesis $(60,61)$. This process has usually been considered to have an absolute requirement in vivo for the presence of $\mathrm{T}$ lymphocytes, which not only release the necessary soluble factors but also express essential cell surface signals, notably the CD40 ligand, which has now been cloned (62). However, the recent demonstration that human lung mast cells also express the CD40 ligand (63), taken in conjunction with their ability to release IL-4 and other costimulatory cytokines such as IL-6, raises the possibility that the direction of IgE synthesis by B lymphocytes in vivo may not be an exclusive property of $\mathrm{T}$ lymphocytes.

Immunoreactivity for interleukin-5 has also been localized to mast cells in bronchial mucosal biopsies from both asthmatics and normal subjects (54), and preliminary information indicates that in response to IgE-dependent stimulation purified human lung mast cells increase their expression of mRNA for IL-5 (64). IL-5 has several important biological properties in vitro in relation to eosinophils. This cytokine stimulates their differentiation (65-67); increases their survival $(68,69)$ by means of delaying apoptosis $(70)$; primes them for increased activity in a number of functional assays (68,71); and is also an eosinophil chemoattractant (72). In addition early reports suggested a role for IL-5 in IgE synthesis by B lymphocytes $(73,74)$, although subsequent studies have not been able to confirm this.

Interleukin- 6 is produced by the human mast cell line HMCI and IL-6 immunoreactivity has again been localized to mast cells in bronchial biopsies (54). This cytokine induces the terminal differentiation of B lymphocytes and their activation for Ig synthesis $(74,75)$ and also stimulates the proliferation of $\mathrm{T}$ lymphocytes (76). In addition, it serves a costimulatory role in antigen presentation, and this action may be relevant in the context of the recent report that highly purified mast cells express class II major histocompatibility complex (MHC) and can apparently present antigens to T lymphocytes (77).

In addition to IL-4, IL-5, IL-6 and TNF- $\alpha$, there are also reports of IL-8 in association with human mast cells. IL-8 was first described as a neutrophil priming agent and chemoattractant $(78,79)$; it is now also recognized to be chemotactic for $\mathrm{T}$ lymphocytes (80) and, when they are primed by prior exposure to other cytokines such as IL-5, IL-3 and GM-CSF. for eosinophils $(81,82)$. Stimulated $\mathrm{HMCI}$ cells have been shown to synthesize and release IL-8 (83). Immunoreactive IL-8 has also been localized to cytoplasmic granules in human skin mast cells following stimulation with anti-IgE, but no evidence was found of preformed IL-8 in unstimulated mast cells (83). IL-8 immunoreactivity in mucosal biopsies from asthmatics, on the other hand, is very largely confined to bronchial epithelial cells (84), which may reflect a lower degree of stimulation in chronic disease. Several forms of neutrophil chemotactic activity have been described in the serum of patients with asthma. A high molecular weight form is detectable following allergen challenge, appearing within minutes and persisting for at least $24 \mathrm{~h}(85,86)$. It is believed to derive from mast cells because the time course of its appearance parallels that of histamine; in addition its release is inhibited by pretreatment with either sodium cromoglycate or salbutamol $(86,87)$. Its identity is unknown, but the high molecular weight of $600 \mathrm{kDa}$ has suggested that it represents a soluble factor conjugated to a serum protein, such as $\alpha_{2}-$ macroglobulin, which is approximately this size and which can bind a number of cytokines. It is possible that IL-8 accounts for part of this activity, and the findings from murine mast cells allow speculation that other members of the chemokine family may also be involved.

\section{MAST CELL CYTOKINES AND ASTHMA}

The identification of cytokines relevant to allergic inflammation within mast cells raises the question of the relative contribution of this particular cellular source in relation to other potential sources of cytokine synthesis within the airways. Increased levels of TNF- $\alpha$ and IL- 6 have been reported in BAL fluid from symptomatic compared to asymptomatic asthmatics (88) and, in a separate report, elevated BAL fluid levels of IL-4 were identified in allergic but not nonallergic asthma (89). The derivation of these cytokines has been investigated by in situ hybridization to examine cytokine mRNA expression in cells recovered by BAL. These studies identify increased numbers of cells expressing mRNA for TNF- $\alpha$, IL-2, IL-4, IL-5 and GM-CSF, but not IFN- $\gamma$ in asthma $(90,91)$, and also an increase in the numbers of cells expressing IL-4, IL-5 and GM-CSF mRNA $24 \mathrm{~h}$ after allergen challenge (92). Dual fluorescence and immunomagnetic cell separation techniques have demonstrated that the BAL cells expressing IL-4 and IL-5 mRNA are predominantly CD2+ T lymphocytes. While such studies are informative about luminal events, they only provide an indirect reflection of events within the airway wall, however, because the cellular profile of BAL fluid and mucosal biopsies differs. In situ hybridization on bronchial biopsies identifies the presence of cells expressing IL-5 mRNA in those from symptomatic asthmatics but not those from asymptomatic asthma nor those from normal subjects (93). A significant increase in the number of cells expressing mRNA for IL-5 and GM-CSF, together with a trend towards increase in those expressing mRNA for IL-2 and IL-4, has also been demonstrated in bronchial biopsies obtained from atopic asthmatics $24 \mathrm{~h}$ after 
allergen challenge (22). Neither of these studies, however, determined the cellular provenance of these cytokines.

In the absence of firm information about the relative importance of the various potential sources of cytokines within the airway wall, it has frequently been assumed that IL-4 and IL-5 are derived mainly or exclusively from T lymphocytes. Evidence of the increased expression of these cytokines in asthma has been seen as supporting the concept that there is selective expansion of a subpopulation of $\mathrm{T}$ lymphocytes analogous to the Th2 subset described in long term murine T lymphocyte clones (94). TNF- $\alpha$ and IL-8, on the other hand, have both been considered to originate predominantly from the monocyte/macrophage population. One feature of cytokine biology that has become increasingly clear, however, is the apparent redundancy in the system, with a diversity of cell types capable of producing a particular cytokine. Thus, the addition of mast cells to the list of potential sources of cytokines within the airway wall raises the question of the significance of this in relation to allergic inflammation.

Although it would clearly be of interest to know whether cytokines of mast cell origin play an obligatory role in any of the pathophysiological manifestations of asthma, there is no direct evidence relating to this in humans. Moreover, the information from animal studies is conflicting. For example, $\mathrm{W} / \mathrm{W}^{\mathrm{V}}$ mice, which are genetically almost entirely deficient of mast cells, are unable to develop an IgE-dependent cutaneous late-phase response (in which the cellular infiltrate comprises neutrophils almost entirely) (95). On the other hand these mice are nevertheless able to mount an effective pulmonary eosinophilic inflammatory response to transnasally administered parasite extract despite their lack of mast cells (96). $\beta 2$ adrenoreceptor antagonists, which are potent inhibitors of mast cell degranulation in vitro (25), do not prevent the development of a late response following allergen challenge in asthmatics (26), nor when taken regularly over several weeks do they reduce BAL fluid eosinophilia (97). However, the influence of these agents on cytokine release from human mast cells has not yet been investigated, and there is also evidence to suggest that tolerance to their effects on mast cells develops in asthma (98).

Their ability to store cytokines in a preformed state and to release them rapidly in response to IgE-dependent activation suggests that mast cells may be responsible for the initial cellular recruitment following allergen exposure. The immediate release of IL-4 and TNF- $\alpha$, for example, would be expected to result in increased expression of adhesion molecules such as E-selectin, ICAM-1 and VCAM-1 in response to allergen challenge and consequent early recruitment of eosinophils and other leukocytes using these pathways. Consistent with this, in the cutaneous late-phase reaction an influx of inflammatory cells is evident as early as $2 \mathrm{~h}(99)$, which would seem too soon to be a result of the release of newly synthesized cytokines from $\mathrm{T}$ lymphocytes. In addition, continued cytokine release from mast cells in the presence of persistent antigenic stimulation, acting in conjunction with cytokines derived from other cellular sources such as $\mathrm{T}$ lymphocytes, may be important in maintaining the chronicity of the inflammatory response. Of particular relevance are the likely effects of mast cell cytokines on eosinophils. IL-4, IL-5 and IL-8 can all act as chemotactic stimuli, IL-5 prolongs their survival by delaying apoptosis, and both IL- 5 and TNF- $\alpha$ increase their degree of functional activation.

Coincident with the chronic inflammatory response in asthma is a parallel process of healing and regeneration which may be accompanied by fibrosis. Best described is the deposition beneath the epithelium of a thick layer of connective tissue comprising primarily collagens types I, III and V and fibronectin (100). This is believed to be synthesized by a population of myofibroblasts which are normally present at this site but which are increased in number in asthma (101). Its pathophysiological significance is unclear, but it may serve as a marker for fibrogenic activity more generally within the airway, and moreover in small airways its mechanical effect will be proportionately greater so that it may itself adversely influence airway function.

Mast cell mediator release may be involved in this fibrotic response. Mast cells have been implicated in several other diseases involving fibrosis, including scleroderma (102) and certain forms of pulmonary fibrosis (103). The classical mast cell degranulation products, histamine (104), heparin (105) and tryptase (106), all have the potential to contribute while cytokine production by mast cells may also be implicated. In particular, TNF- $\alpha$ has been shown to be mitogenic for fibroblasts both in vitro and in vivo (107), and IL-4 stimulates fibroblasts both to proliferate (108) and to synthesize matrix proteins such as types I and III collagen and fibronectin (109). However, the most potent profibrotic cytokine known is transforming growth factor- $\beta$. Transforming growth factor- $\beta$ mRNA has been described in murine mast cells (110), and canine mastocytoma cells have been reported to release TGFß1 (111), but these finding have not yet been extended to human mast cells.

\section{ANTI-INFLAMMATORY THERAPY AND MAST CELL CYTOKINE PRODUCTION}

Corticosteroids exert a potent anti-inflammatory effect in asthma and form a mainstay of therapy. Several studies have shown that, in addition to reducing symptoms and improving physiological indices of lung function, they also decrease mucosal inflammation. Following a six-week course of beclomethasone dipropionate, for example, there was decreased $\mathrm{T}$ lymphocyte activation in BAL fluid (112) and reduced numbers of $\mathrm{T}$ lymphocytes, eosinophils and mast cells in bronchial biopsies (113). BAL fluid levels of the mast cell products histamine and tryptase were also reduced (114) but, as histamine release from purified mast cells is not affected by dexamethasone (115), this may be secondary to reduced mast cell numbers rather than a direct effect on mediator release.

There is less information about the influence of corticosteroids on mast cell cytokine production. Corticosteroids inhibit synthesis of a number of cytokines by $\mathrm{T}$ lymphocytes in vitro, but their effects on mast cell cytokine production 
have not yet been extensively investigated. However, preliminary evidence indicates that TNF- $\alpha$ synthesis and release by murine mast cells are both inhibited in vitro by dexamethasone, and that this inhibition is likely at least in part to account for the reduction in the cutaneous late phase inflammatory response observed in mice following pretreatment with dexamethasone (116). In asthma a significant reduction in BAL fluid cells expressing mRNA for IL-4 and IL-5 has been demonstrated following a short course of oral prednisolone (117), but as discussed above the proportion of mast cells in BAL fluid is very small. The effects of steroids on cytokine mRNA and protein expression in biopsy specimens from asthmatic subjects have not yet been reported.

The potent anti-inflammatory agent cyclosporin has been shown to have some beneficial action in asthma and may be useful in patients whose condition is not fully controlled with corticosteroids or who are experiencing an unacceptable level of side effects (118). Cyclosporin acts by binding to a cytoplasmic receptor, cyclophilin, and the complex then inhibits the transcriptional activation of a number of cytokine genes. Although its effects have been most widely explored in relation to $\mathrm{T}$ lymphocytes, recent evidence indicates that both cyclosporin and the related immunosuppressive drug FK506 inhibit production of several cytokines, including IL-2, IL-3, IL-4 and GM-CSF by murine mast cell lines (119). Cyclosporin can also partially inhibit release of histamine and $\mathrm{PGD}_{2}$ from human lung mast cells (120), and so these observations allow speculation that its anti-inflammatory action may in part be mediated by an effect on mast cells.

\section{CONCLUSION}

The recognition that mast cells can serve as an important source of cytokines has greatly extended our view of their potential role in the pathogenesis of asthma. Rather than releasing mediators that account only for the immediate bronchoconstrictor reaction to allergen challenge, it now seems probable that mast cells contribute both to the initiation and to the maintenance of the inflammatory response via the synthesis and release of cytokines. Figure 3 summarizes the possible ways in which mast cell cytokines may be implicated in the regulation of allergic inflammation.

Furthermore, the findings in relation to murine mast cells suggest that the profile of human mast cell cytokine production is likely to be substantially wider than currently recognized, perhaps including fibrogenic cytokines and other members of the chemokine family. It is also interesting that murine mast cells are able to produce not only 'Th2-like' cytokines such as IL-3, IL-4, IL-5 and GM-CSF, but additionally IL-2 and IFN- $\gamma$, which are more usually associated with $T_{1}$ responses and delayed-type hypersensitivity. Indeed, mast cells have been linked to the development of delayed-type hypersensitivity responses $(121,122)$ and such responses are reduced in mast cell deficient $\mathrm{W} / \mathrm{W}^{v}$ mice (123). These observations raise the possibility that the profile of mast cell cytokine production might vary in different situations, as is recognized to be the case with T lymphocyte cytokine profiles.

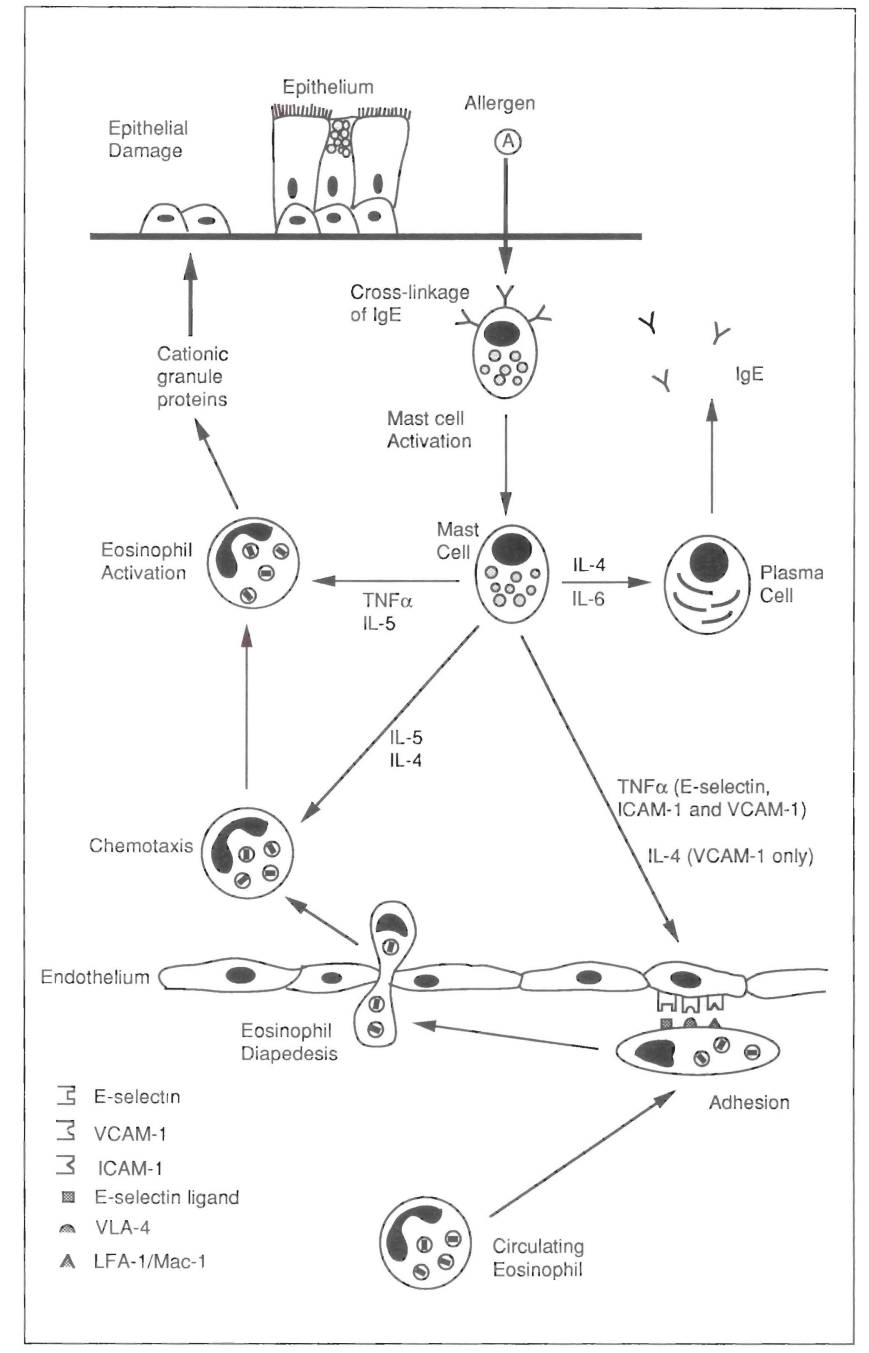

Figure 3) Potential sites at which mast cell cytokines may be involved in the regulation of allergic inflammation. ICAM-I Intercellular adhesion molecule-I; Ig Immunoglobulin; IL Interleukin; LFA-I Lymphocyte function associated antigen-I; TNF Tumour necrosis factor; VCAM-I Vascular cell adhesion molecule-I; VLA4 Very late antigen-4. (With assistance of Mrs S Wilson)

In discussions of the cellular and molecular basis of asthma, there has not infrequently been a tendency to focus on one cell type in preference to others as being of paramount importance. However, it is becoming increasingly apparent that a great variety of cells, both inflammatory and structural, are implicated in the inflammatory response underlying asthma, and that mast cells must be added to the list of potential cells involved together with $\mathrm{T}$ lymphocytes, macrophages, bronchial epithelial cells, eosinophils and fibroblasts. Critical to the future understanding of the induction and resolution of the airway inflammatory process will be an appreciation of the mechanisms of control of cytokine synthesis and release and the similarities and differences in these respects between different cell populations.

ACKNOWLEDGEMENTS: This work was supported by the Medical Research Council (UK). 


\section{REFERENCES}

1. Dale HH, Laidlaw PP. The physiological action of $\beta$-iminazolylethylamine. J Physiol (Lond) 1910;41:318-44.

2. Riley JF. Histamine in tissue mast cells. Science 1953;1 18:332-3.

3. Samuelsson B. Leukotrienes: mediators of immediate hypersensitivity reactions and inflammation. Science 1983;220:568-75

4. Murray JJ, Tonnel AB, Brash AR, et al. Release of prostaglandin $\mathrm{D}_{2}$ into human airways during acute antigen challenge. N Engl J Med 1986;315:800-4.

5. Wenzel SE, Fowler AA III, Schwartz LB. Activation of pulmonary mast cells by bronchoalveolar lavage: in vivo release of histamine and tryptase in atopic subjects with and without asthma. Am Rev Respir Dis 1988;137:1002-6.

6. Wenzel SA, Larsen GL, Johnston K, Voelkel NF, Westcott JY. Elevated levels of leukotriene $\mathrm{C} 4$ in bronchoalveolar lavage fluid from atopic asthmatics after endobronchial allergen challenge. Am Rev Respir Dis 1990;142:112-9.

7. Rafferty P, Beasley CR, Holgate ST. The contribution of histamine to bronchoconstriction produced by inhaled allergen and adenosine 5 monophosphate in asthma. Am Rev Respir Dis $1987 ; 136: 369-73$.

8. Beasley RCW, Featherstone RL. Church MK, et al. Effect of a thromboxane receptor antagonist on $\mathrm{PGD}_{2}$ - and allergen-induced bronchoconstriction. J Appl Physiol 1989;66:1685-93

9. Taylor IK, O'Shaughnessy KM, Fuller RW, Dollery CT. Effect of a cysteinyl-leukotriene antagonist ICI204,219 on allergen-induced broncho-constriction and airway hyper-responsiveness in atopic subjects. Lancet 1991;337:690-4.

10. Huber HL. Koessler KK. The pathology of bronchial asthma. Arch Intern Med 1922;30:689-760.

11. Houston JC, de Navasquez S, Trounce JR. A clinical and pathological study of fatal cases of status asthmaticus. Thorax 1953;8:207-13.

12. Cardell BS, Pearson RSB. Death in asthmatics. Thorax 1959;14:341-52.

13. Messer JW, Peters GA, Bennett WA. Causes of death and pathologic findings in 304 cases of bronchial asthma. Dis Chest 1960:38:616-24

14. Glynn AA, Michaels L. Bronchial biopsy in chronic bronchitis and asthma. Thorax 1960;15:142-53.

15. Salvato G. Some histological changes in chronic bronchitis and asthma. Thorax 1968;23:168-72.

16. Beasley R, Roche WR, Roberts JA, Holgate ST. Cellular events in the bronchi in mild asthma and after bronchial provocation. Am Rev Respir Dis 1989;139:806-17.

17. Jeffery PK, Wardlaw AJ, Nelson FC, Collins JV, Kay AB. Bronchial biopsies in asthma. An ultrastructural, quantitative study and correlation with hyperreactivity. Am Rev Respir Dis 1989;140:1745-53

18. Azzawi M, Bradley B, Jeffery PK, et al. Identification of activated T lymphocytes and eosinophils in bronchial biopsies in stable atopic asthma. Am Rev Respir Dis 1990;142:1407-13.

19. Djukanovic R, Wilson JW, Britten KM, et al. Quantitation of mast cells and eosinophils in the bronchial mucosa of symptomatic atopic asthmatics and healthy control subjects using immunohistochemistry. Am Rev Respir Dis 1990;142:863-71.

20. Bousquet J, Chanez P, Lacoste JY, et al. Eosinophilic inflammation in asthma. N Engl J Med 1990;323:1033-9.

21. Bradley BL, Azzawi M, Jacobson M, et al. Eosinophils, T-lymphocytes, mast cells, neutrophils, and macrophages in bronchial biopsy specimens from atopic subjects with asthma: comparison with biopsy specimens from atopic subjects without asthma and normal control subjects and relation to bronchial hyperresponsiveness. J Allergy Clin Immunol 1991;88:661-74.

22. Bentley AM, Menz G, Storz C, et al. Identification of T lymphocytes, macrophages, and activated eosinophils in the bronchial mucosa in intrinsic asthma: relationship to symptoms and bronchial responsiveness. Am Rev Respir Dis 1992;146:500-6.

23. Saetta M, DiStefano A, Maestrelli P, et al. Airway mucosal inflammation in occupational asthma induced by toluene diisocyanate. Am Rev Respir Dis 1992;145:160-8.

24. Bentley AM, Maestrelli P, Saetta M, et al. Activated $\mathrm{T}$-lymphocytes and eosinophils in the bronchial mucosa in isocyanate-induced asthma. J Allergy Clin Immunol 1992;89:821-9.

25. Church MK, Hiroi J. Inhibition of IgE-dependent histamine release from human dispersed lung mast cells by anti-allergic drugs and salbutamol. Br J Pharmacol 1987;90:421-9.

26. Cockcroft DW, Murdock KY. Comparative effects of inhaled salbutamol, sodium cromoglycate, and beclomethasone dipropionate on allergen-induced early asthmatic responses, late asthmatic responses, and increased bronchial responsiveness to histamine. J Allergy Clin Immunol 1987;79:734-40.

27. Haahtela T, Järvinen M, Kava T, et al. Comparison of a $\beta 2$-agonist, terbutaline, with an inhaled corticosteroid, budesonide, in newly detected asthma. N Engl J Med 1991;325:388-92.

28. Mann JS, Clement P, Sheridan AQ, Soryal I, Fairfax AJ, Holgate ST. Inhaled lodoxamide tromethamine in the treatment of perennial asthma: a double-blind placebo-controlled study. J Allergy Clin Immunol 1985;76:83-90.

29. Pesci A, Foresi A, Bertorelli G, Chetta A, Oliveri D. Histochemical characteristics and degranulation of mast cells in epithelium and lamina propria of bronchial biopsies from asthmatic and normal subjects. Am Rev Respir Dis 1993; 147:684-9.

30. Flint KC, Leung KBP, Hudspith BN, Brostoff J, Pearce FL, Johnson NM. Bronchoalveolar mast cells in extrinsic asthma: a mechanism for the initiation of antigen specific bronchoconstriction. Br Med J 1985;291:923-6.

31. Wardlaw AJ, Dunnette S, Gleich GJ, Collins JV, Kay AB. Eosinophils and mast cells in bronchoalveolar lavage in subjects with mild asthma. Relationship to bronchial reactivity. Am Rev Respir Dis 1988;137:62-9.

32. Casale TB, Wood D, Richerson HB, et al. Elevated bronchoalveolar lavage fluid histamine levels in allergic asthmatics are associated with methacholine bronchial hyperresponsiveness. J Clin Invest 1987;79:1197-203.

33. Wardlaw AJ, Kay H, Cromwell O, Collins JV, Kay AB. Leukotrienes, LTC4 and LTB4, in bronchoalveolar lavage in bronchial asthma and other respiratory diseases. J Allergy Clin Immunol 1989 84:19-26.

34. Chung SW, Wong PMC, Shen-Ong G, Ruscetti S, Ishizaka T, Evans CJ. Production of granulocyte-macrophage colony-stimulating factor by Abelson virus-induced tumorigenic mast cell lines. Blood 1986;68:1074-81.

35. Humphries RK, Abraham S, Krystal G, Lansdorp P, Lemoine F, Eaves CJ. Activation of multiple haematopoietic growth factor genes in Abelson virus-transformed myeloid cells. Exp Haematol 1988;16:774-81.

36. Brown MA, Pierce JH, Watson CJ, Falco J, Ihle JN, Paul WE. $\mathrm{B}$ cell stimulatory factor-1/interleukin-4 $\mathrm{mRNA}$ is expressed by normal and transformed mast cells. Cell 1987;50:809-18.

37. Plaut M, Pierce JH, Watson CJ, Hanley-Hyde J, Nordan RP, Paul WE. Mast cell lines produce lymphokines in response to cross-linkage of FceR 1 or to calcium ionophores. Nature 1989:339:64-7.

38. Burd PR, Rogers HW, Gordon JR, et al. Interleukin 
3-dependent and -independent mast cells stimulated with IgE and antigen express multiple cytokines. J Exp Med 1989;170:245-7.

9. Wodnar-Filipowicz A, Heusser C, Moroni C. Production of the haematopoietic growth factors GM-CSF and interleukin-3 by mast cells in response to $\operatorname{IgE}$ receptor-mediated activation. Nature 1989;339:150-2.

40. Gordon JR, Galli SJ. Mast cells as a source of both preformed and immunologically inducible TNF- $\alpha /$ cachectin. Nature 1990;346:274-6.

41. Gordon JR, Galli SJ. Release of both preformed and newly synthesised tumour necrosis factor $\alpha(\mathrm{TNF}-\alpha) /$ cachectin by mouse mast cells stimulated via the FceRI. A mechanism for the sustained action of mast cell-derived TNF- $\alpha$ during IgE-dependent biological responses. J Exp Med 1991;174:103-7.

42. Pober JS, Bevilacqua MP, Mendrick DL, Lapierre LA, Fiers W, Gimbrone MA Jr. Two distinct monokines, interleukin 1 and tumor necrosis factor, each independently induce biosynthesis of the same antigen on the surface of cultured human vascular endothelial cells. J Immunol 1986;136:1680-7.

43. Pober JS, Gimbrone MA Jr, Lapierre LA, et al. Overlapping patterns of activation of human endothelial cells by interleukin 1 , tumour necrosis factor, and immune interferon. $\mathbf{J}$ Immunol 1986;137:1893-6.

44. Thornhill MH, Haskard DO. IL-4 regulates endothelial cell activation by IL-1, tumor necrosis factor, or IFN- $\gamma$. J Immunol 1990; 145:865-72.

45. Silberstein DS, David JR. Tumor necrosis factor enhances eosinophil toxicity to Schistosoma mansoni larvae. Proc Natl Acad Sci USA 1986;83:1055-9.

46. Slungaard A, Vercellotti GM, Walker G, Nelson RD. Tumor necrosis factor $\alpha$ / cachectin stimulates eosinophil oxidant production and toxicity towards human endothelium. J Exp Med 1990;717:2025-41.

47. Ming WJ, Bersani L, Mantovani A. Tumor necrosis factor is chemotactic for monocytes and polymorphonuclear leukocytes. J Immunol 1987;138:1469-74.

48. Kips JC, Tavernier J, Pauwels RA. Tumor necrosis factor causes bronchial hyperresponsiveness in rats. Am Rev Respir Dis 1992;145:332-6.

49. Wheeler AP, Jesmok G, Brigham KL. Tumor necrosis factor's effects on lung mechanics, gas exchange, and airway reactivity in sheep. J Appl Physiol 1990;68:2542-9.

50. Beynon RC, Bissonnette EY, Befus AD. Tumor necrosis factor- $\alpha$ dependent cytotoxicity of human skin mast cells is enhanced by anti-IgE antibodies. J Immunol 1991;147:2253-8.

51. Walsh LJ, Trinchieri G, Waldorf HA, Whitaker D, Murphy GF Human dermal mast cells contain and release tumor necrosis factor $\alpha$, which induces endothelial leukocyte adhesion molecule 1. Proc Natl Acad Sci USA 1991;88:4220-4.

52. Klein LM, Lavker RM, Matis WL, Murphy GF. Degranulation of human mast cells induces an endothelial antigen central to leukocyte adhesion. Proc Natl Acad Sci USA 1989;86:8972-6.

53. Ohkawara Y, Yamauchi K, Tanno Y, et al. Human lung mast cells and pulmonary macrophages produce tumor necrosis factor- $\alpha$ in sensitized lung tissue after IgE receptor triggering. Am J Respir Cell Mol Biol 1992;7:385-92.

54. Bradding P, Roberts JA, Britten KM, et al. Interleukins (IL)-4, $-5,-6$ and TNF $\alpha$ in normal and asthmatic airways: evidence for the human mast cell as a source of these cytokines. Am J Respir Cell Mol Biol 1994. (In press)

55. Bissonnette EY, Enciso JA, Befus AD. Mechanism of mast cell TNFo-dependent cytotoxicity. J Immunol 1993;150:147A. (Abst)

56. Bradding P, Feather IH, Howarth PH, et al. Interleukin 4 is localised to and released by human mast cells. J Exp Med 1992;176:1381-6.
57. Dobrina A, Menegazzi R, Carlos TM, et al. Mechanisms of eosinophil adhesion to cultured vascular endothelial cells. Eosinophils bind to the cytokine-induced endothelial ligand vascular cell adhesion molecule-1 via the very late activation antigen-4 integrin receptor. J Clin Invest 1991;88:20-6.

58. Schleimer RP, Sterbinsky SA, Kaiser J, et al. IL-4 induces adherence of human eosinophils and basophils but not neutrophils to endothelium. J Immunol 1992;148:1086-92.

59. Dubois GR, Bruijnzeel PLB. IL-4 induced mobilization of eosinophils in allergic inflammation. Allergy 1993;48:7. (Abst)

60. DelPrete G, Maggi E, Parronchi P, et al. IL-4 is an essential factor for the $\operatorname{IgE}$ synthesis induced in vitro by human $\mathrm{T}$ cell clones and their supernatants. J Immunol 1988;140:4193-8.

61. Pene J, Rousset F, Briere F, et al. IgE production by normal human lymphocytes is induced by interleukin-4 and suppressed by interferons $\gamma$ and $\alpha$ and prostaglandin E2. Proc Natl Acad Sci USA 1988;85:6880-4.

62. Spriggs MK, Armitage RJ, Strockbine L, et al. Recombinant human CD40 ligand stimulates B cell proliferation and immunoglobulin E synthesis. J Exp Med 1992;176:1543-50.

63. Gauchet J-F, Henchoz S, Mazzel G, et al. Induction of human IgE synthesis in B cells by mast cells and basophils. Nature 1993;365:340-3.

64. Jaffe JS, Schulman ES. Activation of human lung mast cells induces early expression of IL-5 mRNA but not IL-3, IL-4 and GM-CSF. J Immunol 1993;150:147A. (Abst)

65. Campbell HD, Tucker WQJ, Hort Y, et al. Molecular cloning, nucleotide sequence, and expression of the gene encoding human eosinophil differentiation factor (interleukin 5). Proc Natl Acad Sci USA 1987;84:6629-33.

66. Clutterbuck EJ, Hirst EMA, Sanderson CJ. Human interleukin-5 (IL-5) regulates the production of eosinophils in human bone marrow cultures: comparison and interaction with IL-1, IL-3, IL-6, and GM-CSF. Blood 1989;73:1504-6.

67. Clutterbuck EJ, Sanderson CJ. Regulation of human eosinophil precursor production by cytokines: a comparison of recombinant human interleukin-1 (rhIL-1), rhIL-3, rhIL-5, rhIL-6 and rh granulocyte-macrophage colony-stimulating factor. Blood 1990;75:1774-9.

68. Lopez AF, Sanderson CJ, Gamble JR, Campbell HD, Young IG, Vadas MA. Recombinant human interleukin 5 is a selective activator of human eosinophil function. J Exp Med 1988;167:219-24.

69. Tai P-C, Sun L, Spry CJF. Effects of IL-5, granulocyte/macrophage colony-stimulating factor (GM-CSF) and IL-3 on the survival of human blood eosinophils in vitro. Clin Exp Immunol 1991;85:312-6.

70. Stern M, Meagher L, Savill J, Haslett C. Apoptosis in human eosinophils. Programmed cell death in the eosinophil leads to phagocytosis by macrophages and is modulated by IL-5. J Immunol 1992;148:3543-9.

71. Fujisawa T, Abu-Ghazaleh R, Kita H, Sanderson CJ, Gleich G. Regulatory effect of cytokines on eosinophil degranulation. J Immunol 1990;144:642-6.

72. Wang JM, Rimaldi A, Biondi A, Chen ZG, Sanderson CJ, Mantovani A. Recombinant human interleukin 5 is a selective eosinophil chemoattractant. Eur J Immunol 1989;19:701-5.

73. Pene J, Rousset F, Briere F, et al. Interleukin 5 enhances interleukin 4-induced IgE production by normal human B cells. The role of soluble CD23 antigen. Eur J Immunol 1988;18:929-35.

74. Vercelli D, Jabari HH, Arai K-I, Yokota T, Geha RS. Endogenous interleukin 6 plays an obligatory role in interleukin 4-dependent human IgE synthesis. Eur J Immunol 1989;19:1419-24.

75. Muraguchi A, Hirano BT, Matsuda T, Horii Y, Nakajima K, Kishimoto T. The essential role of B cell stimulatory factor 2 (BSF-2/IL-6) for the terminal differentiation of B cells. J Exp 
Med 1988;167:332-44.

76. Tosato G, Pike SE. Interferon- $\beta 2$ /interleukin 6 is a co-stimulant for human T lymphocytes. J Immunol 1988;141:1556-62.

77. Fox CC, Jewell SD. Antigen presentation by highly enriched mast cell populations. J Immunol 1993;150:146A. (Abst)

78. Yoshimura T, Matsushima K, Openheim JJ, Leonard EJ. Neutrophil chemotactic factor produced by lipopolysaccharide (LPS) stimulated human blood mononuclear leukocytes. I. Partial characterization and separation from interleukin-1 (IL-1). J Immunol 1987;139:788-93.

79. Matsushima K, Morishita K, Yoshimura T. Molecular cloning of cDNA for a human monocyte derived neutrophil chemotactic factor (MDNCF) and the induction of MDNCF mRNA by interleukin-1 and tumor necrosis factor. J Exp Med 1988;167:1883-93.

80. Larsen CG, Anderson AO, Appella E, Oppenheim JJ, Matsushima K. The neutrophil-activating protein (NAP-1) is also chemotactic for T lymphocytes. Science 1989;243:1464-6.

81. Warringa RAJ, Koenderman L, Kok PTM, Kreukniet J, Bruijnzeel PLB. Modulation and induction of eosinophil chemotaxis by granulocyte-macrophage colony-stimulating factor and interleukin-3. Blood 1991:77:2694-700.

82. Warringa RAJ, Schweizer RC, Maikoe T, Kuijper PHM, Bruijnzeel PLB, Koenderman L. Modulation of eosinophil chemotaxis by interleukin-5. Am J Respir Cell Mol Biol 1992;7:631-6.

83. Möller A, Lippert U, Lessmann D, et al. Human mast cells produce IL-8. J Immunol 1993;151:3261-6.

84. Redington AE, Bradding P, Douglass JA, et al. Bronchial epithelial cytokine production in asthmatics and non-asthmatics. Thorax 1993;48:1081. (Abst)

85. Atkins PC, Norman M, Weiner H, Zweiman B. Release of neutrophil chemotactic activity during immediate hypersensitivity reactions in humans. Ann Intern Med 1977;86:415-8.

86. Atkins PC, Norman ME, Zweiman B. Antigen-induced neutrophil chemotactic activity in man. Correlation with bronchospasm and inhibition by disodium cromoglycate. J Allergy Clin Immunol 1978;62:149-55.

87. Howarth PH, Durham SR, Lee TH, Kay AB, Church MK. Holgate ST. Influence of albuterol, cromolyn sodium and ipratropium bromide on the airway and circulating mediator responses to allergen bronchial provocation in asthma. Am Rev Respir Dis 1985;132:986-92.

88. Broide DH, Lotz M, Cuomo AJ, Coburn DA, Federman EC, Wasserman SI. Cytokines in symptomatic asthma airways. J Allergy Clin Immunol 1992;89:958-67.

89. Walker C, Bode E, Boer L, Hansel TT, Blaser K, Virchow Jr. J-C. Allergic and nonallergic asthmatics have distinct patterns of T-cell activation and cytokine production in peripheral blood and bronchoalveolar lavage. Am Rev Respir Dis 1992;146:109-15.

90. Ying S, Robinson DS, Varney V, et al. TNF $\alpha$ mRNA expression in allergic inflammation. Clin Exp Allergy 1991;21:745-50.

91. Robinson DS, Hamid Q, Ying S, et al. Predominant TH2-like bronchoalveolar T-lymphocyte population in atopic asthma. N Engl J Med 1992;326:298-304.

92. Robinson D, Hamid Q, Bentley A, Ying S, Kay AB, Durham SR. Activation of CD4+ T cells, increased $\mathrm{T}_{\mathrm{H} 2}$-type cytokine mRNA expression, and eosinophil recruitment in bronchoalveolar lavage after allergen challenge in patients with atopic asthma. J Allergy Clin Immunol 1993;92:313-24.

93. Hamid Q, Azzawi M, Ying S, et al. Expression of mRNA for interleukin-5 in mucosal bronchial biopsies from asthma. J Clin Invest 1991;87:1541-6.

94. Mosmann TR, Cherwinski H, Bond MW, Giedlin MA, Coffman RL. Two types of murine helper T cell clone. I.
Definition according to profiles of lymphokine activities and secreted proteins. J Immunol 1986;136:2348-57.

95. Wershil BK, Wang Z-S, Gordon JR, Galli SJ. Recruitment of neutrophils during IgE-dependent cutaneous late phase responses in the mouse is mast cell-dependent. Partial inhibition of the reaction with antiserum against tumor necrosis factor-alpha. J Clin Invest 1991;87:446-53.

96. Nogami M, Suko M, Okudaira H, et al. Experimental pulmonary eosinophilia in mice by Ascaris suum extract. Am Rev Respir Dis 1990;141:1289-95.

97. Adelroth E, Rosenhall L, Johansson S-A, Linden M, Venge P. Inflammatory cells and eosinophilic activity in asthmatics investigated by bronchoalveolar lavage. The effects of antiasthmatic treatment with budesonide or terbutaline. Am Rev Respir Dis 1990;142:91-9.

98. O’ Connor BJ, Aikman SL, Barnes PJ. Tolerance to the nonbronchodilator effects of inhaled $\beta 2$-agonists in asthma. N Engl J Med 1992;327:1204-8.

99. Atkins P, Green GR, Zweiman B. Histologic studies of human skin test responses to ragweed, compund 48/80, and histamine. J Allergy Clin Immunol 1973;51:263-73.

100. Roche WR, Beasley R, Williams JH, Holgate ST. Subepithelial fibrosis in the bronchi of asthmatics. Lancet 1989;i:520-4.

101. Brewster CEP, Howarth PH, Djukanovic R, Wilson J, Holgate ST, Roche WR. Myofibroblasts and subepithelial fibrosis in bronchial asthma. Am J Respir Cell Mol Biol 1990;3:507-11.

102. Hawkins RA, Claman HN, Clark RA, Steigerwald JC. Increased dermal mast cell populations in progressive systemic sclerosis: a link in chronic fibrosis. Ann Intern Med 1985;102:182-6.

103. Kawanami O, Ferrans VJ, Fulmer JD, Crystal RG. Ultrastructure of pulmonary mast cells in patients with fibrotic lung disorders. Lab Invest 1979;40:717-34.

104. Norrby K. Mast cell histamine, a local mitogen acting via $\mathrm{H}_{2}$-receptors in nearby tissue cells. Virchows Archiv B 1980;34:13-20.

105. Roche WR. Mast cells and tumors. The specific enhancement of tumor proliferation in vitro. Am J Pathol 1985;1 19:57-64.

106. Ruoss SJ, Hartmann T, Caughey GH. Mast cell tryptase is a mitogen for cultured fibroblasts. J Clin Invest 1991;88:493-9.

107. Piguet PF, Grau GE, Vassalli P. Subcutaneous perfusion of tumor necrosis factor induces proliferation of fibroblasts, capillaries, and epidermal cells, or massive tissue necrosis. Am J Pathol 1990;136:103-10.

108. Monroe JG, Haldar S, Prystowsky MB, Lammie P. Lymphokine regulation of inflammatory processes: interleukin-4 stimulates fibroblast proliferation. Clin Immunol Immunopathol 1988;49:292-8.

109. Postlethwaite AE, Holness MA, Katai H, Raghow R. Human fibroblasts synthesize elevated levels of extracellular matrix proteins in response to interleukin 4. J Clin Invest 1992;90:1479-85.

110. Tsai M, Gordon JR, Galli SJ. Mast cells constitutively express transforming growth factor $\beta$ mRNA. FASEB J 1990;4:A1944 (Abst.).

111. Pennington DW, Lopez AR, Thomas PS, Peck C, Gold WM. Dog mastocytoma cells produce transforming growth factor beta1. J Clin Invest 1992;90:35-41.

112. Wilson JW, Djukanovic R, Howarth PH, Holgate ST. Inhaled beclomethasone dipropionate down-regulates airway lymphocyte activation in atopic asthma. Am J Respir Crit Care Med 1994;149:86-90.

113. Djukanovic R, Wilson JW, Britten KM, et al. Effect of an inhaled corticosteroid on airway inflammation and symptoms in asthma. Am Rev Respir Dis 1992;145:669-74.

114. Djukanovic R, Walls AF, Wilson JW, et al. The effect of inhaled beclomethasone dipropionate on airway mast cells, histamine and tryptase in atopic asthma. Am Rev Respir Dis 
1991;143:A627. (Abst)

115. Schleimer RP, Schulmann ES, MacGlashan DW Jr, et al, Effects of dexamethasone on mediator release from human lung fragments and purified human lung mast cells. J Clin Invest 1983;71:1830-5.

116. Wershil BK, Gordon JR, Wang Z-S, Lavigne JA, Galli SJ. Dexamethasone (DEX) inhibits IgE-dependent TNF $\alpha$ production by mouse mast cells (MCs) in vitro and suppresses IgE-, mast cell- and TNF- $\alpha$-dependent inflammation in vivo. FASEB J 1992;6:A1716. (Abst)

117. Robinson D, Hamid Q, Ying S, et al. Prednisolone treatment in asthma is associated with modulation of bronchoalveolar lavage cell interleukin-4, interleukin-5, and interferon- $\gamma$ cytokine gene expression. Am Rev Respir Dis 1993;148:401-6.

118. Alexander AG, Barnes NC, Kay AB. Trial of cyclosporin in corticosteroid-dependent chronic severe asthma. Lancet 1992;339:324-8.
119. Hatfield SM, Roehm NW. Cyclosporine and FK506 inhibition of murine mast cell cytokine production. J Pharmacol Exp Ther 1992;260:680-8.

120. Triggiani M, Cirillo R, Lichtenstein LM, Marone G. Inhibition of histamine and prostaglandin $\mathrm{D}_{2}$ release from human lung mast cells by cyclosporin A. Int Arch Allergy Appl Immunol 1989;88:253-5.

121. Gershon RK, Askenase PW, Gershon MD. Requirement for vasoactive amines for production of delayed-type hypersensitivity skin reactions. J Exp Med 1975;142:732-47.

122. Askenase PW, Metzler CM, Gershon RK. Localization of leucocytes in sites of delayed-type hypersensitivity and in lymph nodes: dependence on vasoactive amines. Immunol 1982;47:239-46.

123. Askenase PW. van Loveren H. Krauter-Kops S, et al. Defective elicitation of delayed-type hypersensitivity in W/Wv and Sl/Sld mast cell-deficient mice. J Immunol 1983;131:2687-94. 


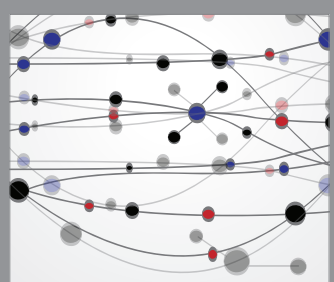

The Scientific World Journal
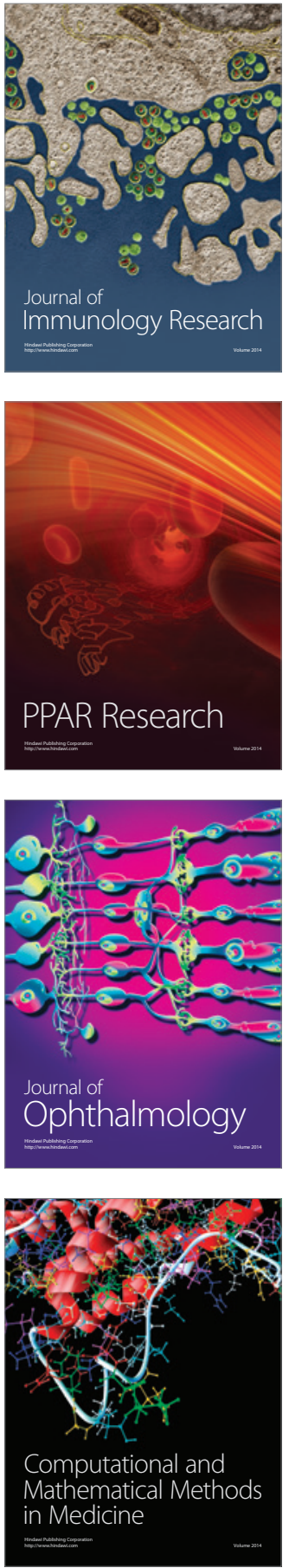

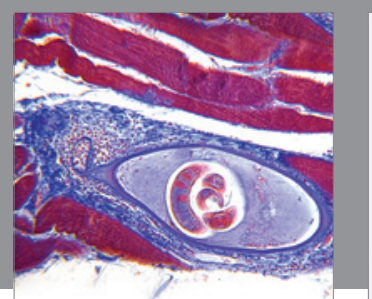

Gastroenterology Research and Practice

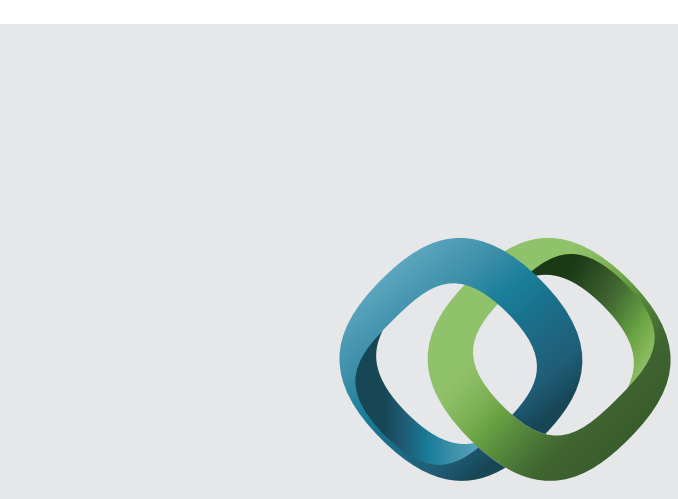

\section{Hindawi}

Submit your manuscripts at

http://www.hindawi.com
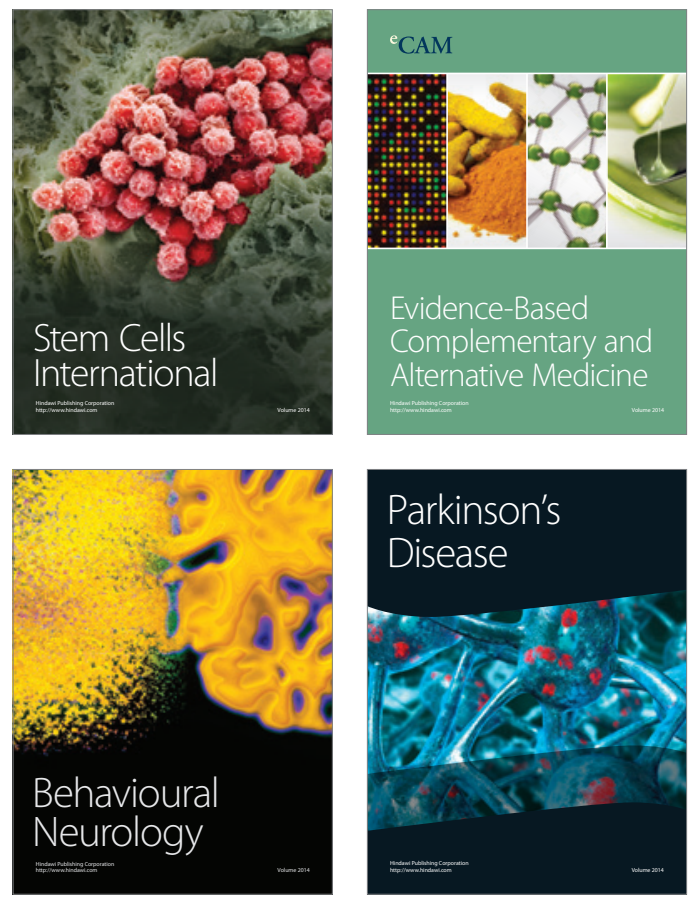
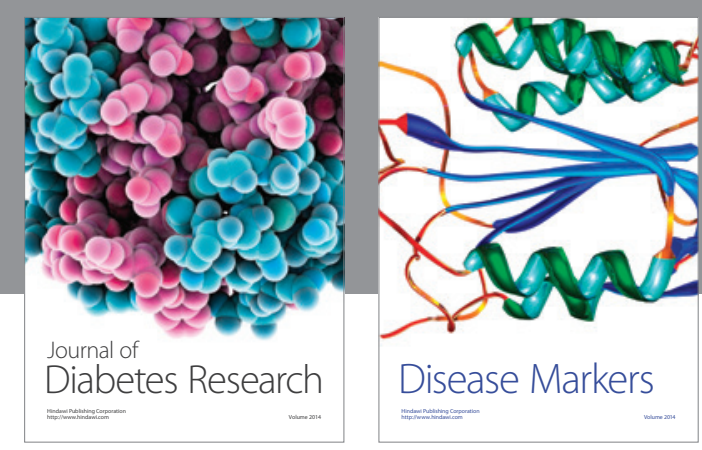

Disease Markers
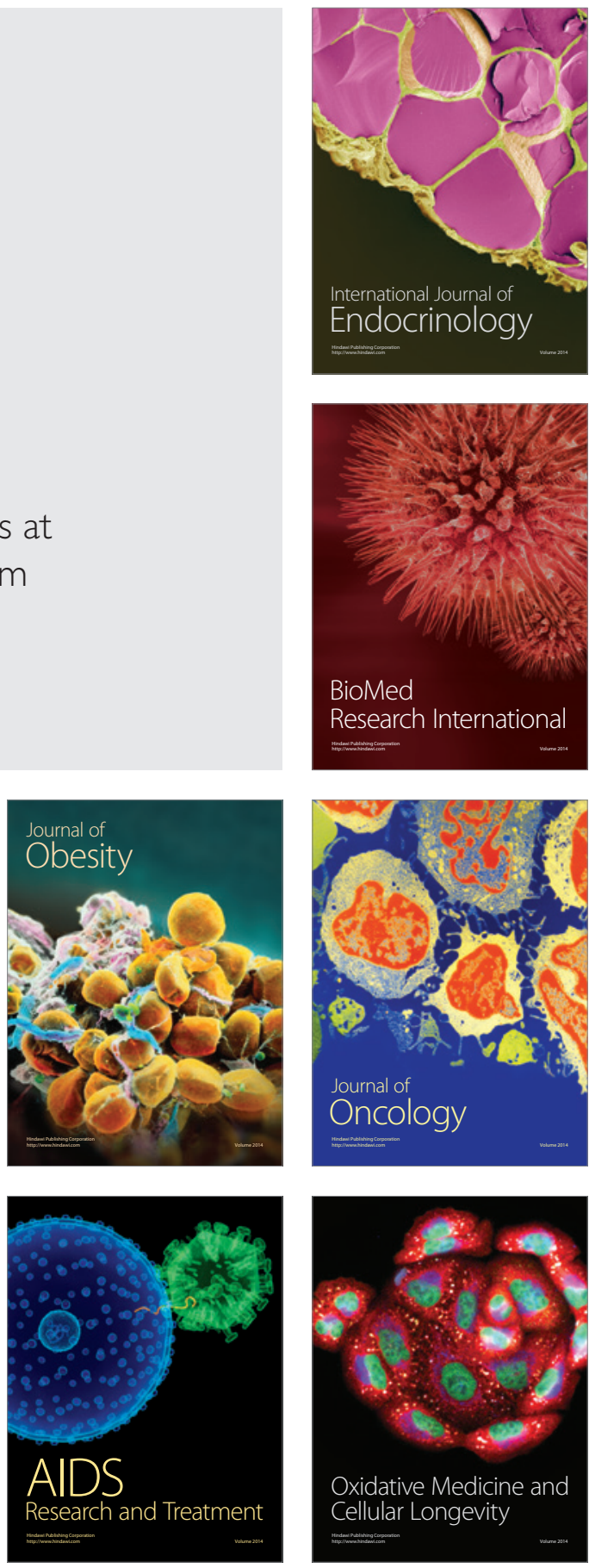